Vol 1. No. 4, Oktober 2021 P-ISSN : 2774-8014, e-ISSN : 2774-7034

\title{
PENGEMBANGAN MEDIA PEMBELAJARAN KOMIK MATEMATIKA SISWA KELAS V SD BERBASIS BUDAYA
}

\author{
ENDAH SULISTYORINI \\ Pascasarjana PMIPA, Universitas Indraprasta PGRI, Jakarta \\ e-mail: endahsulis1313@gmail.com
}

\begin{abstract}
ABSTRAK
Penelitian ini bertujuan untuk mendesain media pembelajaran yang dapat meningkatkan minat peserta didik dalam belajar matematika dan membantu peserta didik dalam memahami soal matematika dalam bentuk soal cerita. Produk media pembelajaran ini memuat materi yang mencangkup dalam standar kompetensi untuk memahami materi kelas V SD. Metode Penelitian yang digunakan adalah ASSURE, yang terdiri dari : (1) Menganalisis Karakteristik Pembelajaran; (2) Menentukan Standard dan Tujuan; (3) Memilih Strategi, Teknologi, Media dan Bahan ajar, (4) Menggunakan Teknologi, Media dan Bahan Ajar; (5) Mengembangkan Partisipasi Peserta Didik; dan (6) Mengevaluasi dan Merevisi. Subyek dalam penelitian ini adalah peserta didik kelas V SD Negeri 16 Pondok Labu, responden dalam penelitian ini sebanyak 20 peserta didik untuk uji coba lapangan terhadap media komik matematika. Instrumen pengumpulan data berupa lembar validasi untuk ahli bidang studi (praktisi), ahli bahasa, ahli materi, ahli media, ahli pengembangan, dan hasil uji lapangan peserta didik kelas V SD. Hasil penelitian ini menunjukan bahwa: (1) Dihasilkan media komik berbasis Budaya pada pembelajaran matematika kelas V SD; (2) Media komik matematika yang dikembangkan berkategori sangat baik untuk digunakan oleh peserta didik SD kelas V, dan (3) pembelajaran dengan media pembelajaran komik matematika dapat mempermudah peserta didik dalam memahami soal cerita serta dapat meningkatkan motivasi belajar peserta didik.
\end{abstract}

Kata Kunci: Media Pembelajaran, Komik Matematika, Berbasis Budaya

\section{ABSTRACT}

This research is aiming for design learning media that can increase students ' interest in learning mathematics and help learners understand math problems in the form of story problems. This Learning media product contains material that covers the standards of competency to understand the material of class V SD. The research method used is ASSURE, consisting of: (1) Analyze learner characteristics; (2) State performance objectives; (3) Select, modify or design media, (4) Utilize Technology, Media, and Material; (5) Require learner response; and (6) Evaluate and revision. The subject in this study was a student of class V elementary School 16 Pondok Labu, the respondent in this study of 20 Students for field trials on comic media mathematics. Data collection instrument in the form of validation sheet for field experts (practitioners), linguists, material experts, media experts, development experts, and student field test results of class V elementary School. The results of this study indicate that: (1) The resulting comic media Based on the Math learning Class V Elementary School; (2) Mathematics comic Media developed very good category for use by students in class V, and (3) learning with the Learning Media Mathematics comic can make it easier for learners to understand the story and can Motivation to learn learners

Keywords: Instructional Media, Math Comics, Cultural Based

\section{PENDAHULUAN}

Fungsi dan tujuan pendidikan nasional merupakan usaha membentuk individu yang mandiri, utamanya membangun kemandirian siswa dalam belajar. Pada prinsipnya pendidikan merupakan usaha sadar dan terencana mewujudkan suasana belajar dan proses pembelajaran agar peserta didik secara aktif mengembangkan potensi dirinya untuk memiliki pengendalian diri, kepribadian, kecerdasan, dan keterampialan proses yang diperlukan dalam kehidupan (Nasution, 2018: 2). 
Salah satu mata pelajaran yang dipelajari dalam pendidikan adalah matematika. Matematika merupakan salah satu cabang ilmu pengetahuan yang mempunyai peranan penting dalam perkembangan ilmu pengetahuan dan teknologi, baik sebagai alat bantu dalam penerapan-penerapan bidang ilmu lain maupun dalam pengembangan matematika itu sendiri (Siagian, 2016:60). Matematika merupakan ilmu dasar yang bersifat abstrak, dimana di satu sisi tidak disukai dan di sisi lain merupakan pelajaran yang menyenangkan bagi yang menguasainya. Untuk itu dalam pembelajaran matematika perlu adanya variasi pembelajaran, agar siswa dapat menerima materi dengan baik dan menarik minat belajar mereka terhadap matematika. Variasi pembelajaran digunakan agar pembelajaran menjadi efektif dan inovatif sehingga hasil belajar siswa menjadi lebih baik (Nugroho dan Shodikin, 2018:22).

Namun kenyataannya adalah tentang problematika siswa Sekolah Dasar dalam pembelajaran matematika banyak ditemui masalah-masalah yang terjadi baik dari segi pendidik maupun peserta didik. Hasil Observasi yang telah dilakukan Fauziah dan Rosnaningsih (2017:52) Motivasi belajar merupakn faktor yang mempengaruhi minat belajar sebesar 79,1\% dan 21,9\% dipengaruhi oleh berbagai persoalan dalam pembelajaran matematik yaitu: kurangnya minat siswa dalam pembelajaran matematika, kurangnya daya kreativitas guru dalam memberikan pembelajaran matematika sehingga siswa merasa tidak tertarik dengan pembelajaran matematika, kegiatan yang monoton sehingga membuat siswa bosan dalam kegiatan pembelajaran, guru mendominasi prosers pembelajaran sehingga menyebabkan siswa menjadi pasif dalam kegiatan belajar mengajar, dan sebagian besar siswa sekolah dasar mengalami kesulitan dalam menyelesaikan soal cerita.

Penelitian yang dilakukan oleh Sutisna (2010:55) Kesalahan yang paling banyak dilakukan oleh siswa adalah kesalahan dalam melakukan perhitungan soal cerita $(64,4 \%)$. Kesalahan terbanyak kedua terjadi pada aspek membuat model matematika $(55,1 \%)$. Kesalahan terbanyak selanjutnya kesalahan pada aspek memahami soal $(35,3 \%)$. Kesalahan yang paling sedikit terjadi adalah kesalahan pada aspek menarik kesimpulan $(33,2 \%)$.

Maka dari itu guru harus melakukan inovasi dalam sistem pembelajaran. Seperti membuat Media pembelajaran yang dikemas dalam bentuk komik dapat digunakan sebagai salah satu variasi media dalam sistem pelajaran. Penelitian yang dilakukan oleh Nadiah dkk (2019:145) melakukan penelitian dengan tersedianya pembelajaran komik matematika tingkat Sekolah Dasar sudah tidak lagi monoton berupa ceramah atau komunikasi satu arah dari guru ke siswa. Komik matematika ini sebagai fasilitas bagi guru bahkan orang tua dari siswa untuk rangkaian kegiatan belajar, baik di sekolah maupun di rumah. Konseptual materi matematika tingkat sekolah dasar sudah ditampilkan dalam bentuk cerita dalam komik.

Perlu pemikiran kreatif dan inovasi untuk menciptakan komik yang memiliki kearifan budaya lokal yang dikemas supaya diterima serta dipelajari secara global. Upaya pelestarian kearifan budaya lokal seperti mengangkat keragaman budaya setempat dapat menjadikan generasi muda memiliki tanggung jawab terhadap lingkungannya. Pelestarian kearifanbudaya lokal dengan mencetak ulang dan membuat budaya baru belum dapat membawa karakteristik budaya lokal menjadi budaya yang diminati generasi muda. Salah satu usaha untuk melestarikan kearifanbudaya lokal melalui sumber belajar dalam pendidikan yang harapannya dapat memberikan pemahaman tentang hasil-hasil budaya setempat kepada generasi penerus.

Sumber belajar untuk mengenalkan kearifanbudaya lokal melalui kegiatan pembelajaran dengan mengefektifkan fungsi media dalam pembelajaran bagi anak (Ma'mur, 2012:30). Pemanfaatan media seharusnya merupakan bagian yang harus mendapat perhatian kita untuk sarana melestarikan kearifanbudaya lokal dalam dunia pendidikan. Terkait dengan usaha pelestarian kearifanbudaya lokal dalam bidang pendidikan, Maunah (2016:150) menyatakan media pembelajaran tidak hanya menjalankan fungsi alih ilmu pngetahuan (transfer of knowledge) tapi juga berfungsi untuk menanamkan nilai (value) serta membangun karakter (Character Building) peserta didik secara berkelanjutan dan berkesinambungan. 
Berdasarkan hasil studi pendahuluan peneliti memiliki tujuan untuk mendesain media pembelajaran yang dapat meningkatkan minat peserta didik dalam belajar matematika dan membantu peserta didik dalam memahami soal matematika dalam bentuk soal cerita. Produk media pembelajaran ini memuat materi yang mencangkup dalam standar kompetensi untuk memahami materi kelas V SD

Berdasarkan pemaparan tersebut penelitian ini layak dilakukan untuk mengembangkan media pembelajaran berupa media komik berbasis Budaya pada siswa kelas V SDN 016 Pondok labu, Jakarta Selatan.

\section{METODE PENELITIAN}

Model Pengembangan yang digunakan dalam penelitian ini mengacu pada model ASSURE yang dikembangkan oleh (Smaldino, 2011). Tahap-tahap penelitian dan pengembangan yang dikembangkan oleh Smaldino adalah: (1) Analyze learner characteristic (menganalisis karakteristik pembelajaran); (2) State Objectives (menyatakan tujuan); (3) Select methods, media, and materials (memilih metode, media, dan materi); (4) Utilize media and materials (memanfaatkan media dan materi); (5) Require learner participation (meminta partisipasi pebelajar); dan (6) Evaluate and Revise (evaluasi dan revisi).

Desain Uji Coba produk hasil pengembangan yang berupa media komik pembelajaran dalam penelitian ini terdiri dari beberapa tahapan yaitu: (1) Validasi produk ahli bidang studi (praktisi), ahli bahasa, ahli materi, ahli media, ahli pengembangan; (2) Revisi I; (3) Uji coba lapangan; (4) Revisi II; dan (5) Produk akhir. Subjek Uji Coba adalah siswa kelas V Sekolah Dasar Negeri 016 Pondok Labu Jakarta Selatan. Subjek uji coba lapangan terdiri dari 20 peserta didik.

Teknik Analisis Data terhadap variabel kualitas komik matematika dilakukan secara deskriptif. Teknik analisis data dilakukan dengan langkah (1) menjumlahkan semua data yang diperoleh dari validator ahli dan praktisi dari butir penilaian yang tersedia dalam instrumen penilaian; (2) menghitung total skor yang diperoleh dari ahli dan praktisi, kemudian dianalisis dengan pedoman konversi nilai. Nilai akumulasi ini merupakan jumlah nilai total dari setiap komponen penilaian. Data dianalisis menggunakan persentase keberhasilan (Purwanto, 2006:102)

$N P=\frac{R}{S M} X 100 \%$

Keterangan:

$\mathrm{NP}=$ Nilai persen skor tiap aspek penilaian komik yang dicari

$\mathrm{R} \quad=$ Jumlah skor tiap aspek penilaian komik

$\mathrm{SM}=$ Skor maksimal tiap aspek penilaian komik

$100=$ Bilangan tetap

Besarnya presentase yang diperoleh kemudia di konversikan kedalam bentuk nilai sesuai penilaian pada Tabel 1 .

Tabel 1. Kriteria Konversi Penilaian Kelayakan Komik Matematika

\begin{tabular}{cccc}
\hline No & $\begin{array}{c}\text { Presentase } \\
\text { Skor }\end{array}$ & $\begin{array}{c}\text { Nilai } \\
\text { Konversi }\end{array}$ & Katagori Kelayakan \\
\hline 1 & $81 \% \leq \mathrm{X} \leq$ & $\mathrm{A}$ & Sangat Layak (SL) \\
& $100 \%$ & & \\
2 & $\begin{array}{c}61 \% \leq \mathrm{X} \leq \\
80 \%\end{array}$ & $\mathrm{~B}$ & Layak (L) \\
& $\begin{array}{c}81 \% \leq \mathrm{X} \leq \\
3\end{array}$ & $\mathrm{C}$ & Cukup Layak (CL) \\
& $60 \%$ & &
\end{tabular}




\begin{tabular}{cccc}
4 & $21 \% \leq \mathrm{X} \leq$ & & \\
$40 \%$ & $\mathrm{D}$ & Kurang Layak (KL) \\
5 & $0 \% \leq \mathrm{X} \leq$ & $\mathrm{E}$ & $\begin{array}{c}\text { Sangat Kurang Layak } \\
(\text { SKL) }\end{array}$ \\
\hline
\end{tabular}

\section{HASIL DAN PEMBAHASAN \\ Hasil Penelitian}

Studi pendahuluan dilakukan untuk mengumpulkan informasi tentang potensi dan permasalahan dalam pembelajaran peserta didik kelas 5 sekolah dasar. Peneliti melakukan observasi dan wawancara kepada guru dan peserta didik di SDN 02, 03, dan 016 Pondok Labu Jakarta Selatan. Dari hasil observasi dan wawancara dapat diketahui bahwa terdapat permasalahan dalam pembelajaran matematika pada peserta didik kelas $5 \mathrm{SD}$, yaitu :

a. Kurangnya antusias pesrta didik dalam pembelajaran matematika jika hanya menggunakan media pembelajaran berupa buku paket atau buku lks sekolah.

b. Peserta didik lebih antusias jika menggunakan media pembelajaran yang inovatif, tetapi tidak semua pendidik menggunakan media pembelajaran selain buku paket dan lks sekolah.

c. Peserta didik sulit memahami soal matematika yang berkaitan dengan model soal cerita, solusi yang diberikan pendidik hanya memberikan soal-soal yang berkaitan dengan kehidupan sehari-hari.

Dari permasalahan yang ada dalam pembelajaran matematika pada peserta didik kelas 5 SD tersebut maka solusi yang peneliti tawarkan yaitu media pembelajaran komik matematika yang merupakan suatu inovasi yang diharapkan dapat meningkatkan antusias dan minat peserta didik dalam belajar matematika, selain itu dapat membantu siswa lebih memahami soal-soal matematika yang berbentuk soal cerita.

Rancangan model pengembangan pembelajaran yang digunakan untuk mengembangkan media pembelajaran matematika berbasis komik kelas V SD menggunakan adaptasi dari model desain sistem ASSURE yang terdiri dari enam tahapan (Smaldino, 2011), tahapan tersebut adalah sebagai berikut :

1. Analyze learner characteristics (Menganalisis karakteristik peserta didik)

Analisis kebutuhan merupakan kegiatan pertama yang harus dilakukan oleh setiap perancang, dikhususnya perancang pembelajaran. Analisis ini bertujuan untuk mengetahui alasan apa yang melatarbelakangi sebuah desain media pembelajaran yang dikembangkan. Teknik pengumpulan data yang digunakan pendesain dalam mengidentifikasi kebutuhan peserta didik adalah angket dan wawancara terhadap tiga sekolah yang berbeda.

Dari beberapa tanggapan guru yang menangani dan mendidik peserta didik yang masih duduk di Sekolah Dasar kelas V, maka disimpukan Karakteristik umum peserta didik kelas V SD adalah anak-anak yang masih dalam tahap perkembangan/ remaja dan aktiv dalam beraktivitas. Dimasa anak-anak kelas V SD mereka masih suka bermain dari pada belajar, mengamati banyak benda dari pada berhitung. Tingkat kejenuhan dan cepat bosan pun masih sangat tinggi. Pada usianya mampu memperoleh strategi yang logis dan abstark tetapi belum dapat berfikir kongkirt. Dari hasil analisis peserta didik, maka penulis akan membuat sebuah media komik yang sederhana dan menggunakan alur cerita yang berkaitan dengan kehidupan sehari-hari, supaya mudah dimengerti oleh peserta didik kelas V SD.

2. State performance objectives (Menetapkan tujuan pembelajaran)

Tahap selanjutnya dalam model ASSURE adalah merumuskan tujuan dan standar. Dengan demikian diharapkan peserta didik dapat memperoleh suatu kemampuan dan kompetensi tertentu dari pembelajaran. Dari hasil analisis pembelajaran yang telah dilakukan, pendesain selanjutnya menyusun bahan mengenai penggunaan teknologi dan 
media pembelajaran untuk menilai pencapaian dari standar dan tujuan belajar menggunakan format $\mathrm{ABCD}$ yaitu :

a. Audiens

Dalam konteks pembelajaran audiens adalah peserta didik. Dalam pembelajaran audiens adalah subjek sekaligus objek. Audiens adalah objek yang "dikenai" sasaran proses belajar mengajar, audiens sebagai pelaku dalam pembelajaran. Audiens yang digunakan peneliti adalah siswa SD kelas V. Intruksi yang peneliti ajukan berfokus pada media pembelajaran dengan menggunakan komik.

b. Behavior

Behavior merupakan tingkah laku, perilaku, dan aktivitas suatu proses. Dalam pembelajaran behavior nampak pada aktivitas peserta didik pada suatu proses pembelajaran. Peserta didik SD kelas V memiliki rasa ingin tahu yang tinggi serta antusias dalam hal-hal baru. Peserta Didik SD kelas V masih sulit dalam menjawab soal matematika dalam bentuk soal cerita, oleh karena itu peserta didik diharapkan adanya suatu perubahan dari yang tidak paham menjadi paham, dari yang kurang minatnya belajar matematika dapat meningkatkan minat belajar matematika, serta dapat memecahkan permasalah soal matematika dalam bentuk soal cerita dengan menggunakan media pembelajaran komik.

c. Condition

Pada saat melakukan observasi peneliti melihat kondisi siswa saat menerima pelajaran dari guru sangatlah bervariasi, ada yang memperhatikan guru menerangkan dan ada yang bermain sendiri. Media yang digunakan guru saat ini dominannya hanya menggunakan buku paket dan strategi yang digunakan masih menggunakan metode ceramah, walau terkadang mereka mencoba media seperti alat peraga dan power point serta menggunakan strategi lainnya. Hal ini yang melandasi peneliti untuk membuat media komik matematika untuk peserta didik SD kelas V.

d. Degree

Degree, artinya adalah perbandingan atau bandingan. Dalam konteks tujuan pembelajaran bertujuan untuk membandingkan kondisi sebelum dan sesudah belajar menggunakan media komik yang akan dibuat oleh peneliti. Berdasarkan dari analisis kebutuhan umum peserta didik peneliti selanjutnya merangkai sebuah tujuan pembelajaran yang diharapkan mampu dicapai oleh peserta didik pada akhir proses pembelajaran.

3. Select Methods, Media and Materials (Memilih metode, media, dan materi)

Tahap ketiga dalam merencanakan pembelajaran yang efektif adalah memilih metode, media dan bahan pelajaran yang sesuai. Strategi pembelajaran yang peneliti pilih adalah berpusat pada siswa dengan menggunakan media pembelajaran komik agar dapat menarik minat dan simpati didik kelas V SD. Slamoto dalam Mutakin dan Sumiati (2015:75) menyatakan "Interest is persisting tendency to pay attention to end enjoy same activity and content". Dengan kata lain minat adalah suatu usaha yang gigih untuk menikmati apa saja yang kita sukai dari aktivitas dan juga dari suatu objek. Minat berperan penting dalam aktivitas seseorang karen tanpa minat yang tinggi kegiatan apapun tidak akan pernah berjalan dengan mestinya.

Maka dari itu peneliti akan mendesain media pembelajaran yang unik dan menarik untuk meningkatkan minat belajar peserta didik, sehingga dapat tercapainaya tujuan pembelajaran yang baik. Dari analisis kebutuhan umum peserta didik, peneliti selanjutnya memilih media komik dengan tokoh ayah ibu, anak (kakak beradik) dan dua sahabat yang berisi cerita tentang kehidupan sehari-hari serta di kombinaskan dengan cerita-cerita kebudayaan betawi. Disini pendesain akan mencoba membuat komik matematika modern dengan tokoh seperti kehidupan sehari-hari dan akan dikombinasikan dengan materi matematika yang sesuai dengan kurikulum pada saat ini, sehingga terciptanya sebuah komik 
matematika yang baik dan menggunakan bahasa yang sederhana untuk peserta didik kelas V SD.

4. Utilize Technology, Media, and Material (Memanfaatkan teknologi, media dan materi)

Tahap keempat adalah menggunakan teknologi, media, dan material. Pada tahap ini peneliti menggunakan teknologi Adobe Photoshop CS3 dan Adobe Ilustrator CS3 untuk membuat komik matematika kelas V Sekolah Dasar. Media yang digunakan adalah media cetak yang berbentuk komik bergambar dan materi yang digunakan adalah materi pelajaran matematika kelas V SD semester I dan semester II.

5. Require learner response (Mengembangkan Partisipasi Peserta didik)

Tahap kelima adalah pendesain akan mengaktifkan partisipasi peserta didik. Belajar tidak cukup hanya mengetahui, tetapi harus bisa merasakan dan melaksanakan serta mengevaluasi hal-hal yang dipelajari sebagai hasil belajar. Pendesain mengaktifkan peserta didik di dalam proses pembelajaran matematika yang menggunakan media komik dan pendesain akan ada sentuhan dari psikologis peserta didik, karena pendesain yakin akan sangat menentukan proses dan keberhasilan belajar.

Setelah mengembangkan partisipasi peserta didik, Pendesain meminta tanggapan dan melakukan uji coba lapangan kepada 20 peserta didik di Sekolah Dasar 016 Pondok Labu Jakarta Selatan, berikut hasil data dari responden :

Tabel 2. Data Hasil Uji Coba Lapangan

\begin{tabular}{cccccc} 
No & Siswa & Total Skor & $\begin{array}{c}\text { Rata-Rata } \\
\text { Skor }\end{array}$ & Persentase & Kriteria \\
\hline 1 & Siswa 1 & 54 & 3,8 & $96,4 \%$ & Layak \\
\hline 2 & Siswa 2 & 52 & 3,7 & $92,8 \%$ & Layak \\
\hline 3 & Siswa 3 & 52 & 3,7 & $92,8 \%$ & Layak \\
\hline 4 & Siswa 4 & 54 & 3,8 & $96,4 \%$ & Layak \\
\hline 5 & Siswa 5 & 55 & 3,9 & $98,2 \%$ & Layak \\
\hline 6 & Siswa 6 & 53 & 3,7 & $92,8 \%$ & Layak \\
\hline 7 & Siswa 7 & 51 & 3,6 & $91,1 \%$ & Layak \\
\hline 8 & Siswa 8 & 54 & 3,8 & $96,4 \%$ & Layak \\
\hline 9 & Siswa 9 & 53 & 3,7 & $92,8 \%$ & Layak \\
\hline 10 & Siswa 10 & 54 & 3,8 & $96,4 \%$ & Layak \\
\hline 11 & Siswa 11 & 54 & 3,8 & $96,4 \%$ & Layak \\
\hline 12 & Siswa 12 & 53 & 3,7 & $92,8 \%$ & Layak \\
\hline 13 & Siswa 13 & 54 & 3,8 & $96,4 \%$ & Layak \\
\hline 14 & Siswa 14 & 51 & 3,6 & $91,1 \%$ & Layak \\
\hline 15 & Siswa 15 & 53 & 3,7 & $92,8 \%$ & Layak \\
\hline 16 & Siswa 16 & 55 & 3,9 & $98,2 \%$ & Layak \\
\hline 17 & Siswa 17 & 50 & 3,5 & $89,2 \%$ & Layak \\
\hline 18 & Siswa 18 & 48 & 3,4 & $85,7 \%$ & Layak \\
\hline 19 & Siswa 19 & 52 & 3,7 & $92,8 \%$ & Layak \\
\hline 20 & Siswa 20 & 54 & 3,8 & $96.4 \%$ & Layak \\
\hline & Hasil & $\mathbf{5 3 , 2}$ & $\mathbf{3 , 7 2}$ & $\mathbf{9 3 , 9 \%}$ & Layak \\
$(\mathbf{J u m}$ lah : 20) & & & & & \\
\hline & & & & & \\
\hline
\end{tabular}


Berdasarkan tabel data hasil uji coba lapangan pada 20 peserta didik terhadap media komik tersebut dapat diketahui bahwa media pembelajaran komik matematika siswa kelas V SD memiliki respon yang baik dan antusias yang tinggi, sehingga media pembelajaran komik matematika layak untuk dikembangkan lebih lanjut.

6. Evaluate and revision (evaluasi dan revisi)

Evaluasi dan revisi yang dilakukan pendesain terdiri dari review oleh pendesain untuk memperoleh tentang bagaimana aspek ketepatan konten menurut ahli bidang studi (praktisi), ahli materi, ahli bahasa, ahli media dan ahli pengembangan. Beberapa masukan dari para ahli akan segera digunakan untuk merevisi produk media pembelajaran.

Dengan melihat perhitungan rekapitulasi terdapat rata-rata dari setiap ahli, yaitu ahli Ahli Bidang Studi (Praktisi) dengan nilai 97,05\%, ahli materi dengan nilai 98, 33\%, ahli bahasa dengan nilai $93,75 \%$, ahli media dengan nilai $84,72 \%$, dan ahli pengembangan dengan nilai 91, 67\%, sehingga diperoleh rata-rata dari ahli keseluruhan adalah 93,10\% dengan nilai konversi A dan Katagori Sangat Layak untuk media pembelajaran komik matematika SD kelas V berbasis Budaya.

Tabel 3. Hasil Revisi Uji Coba Ahli Materi

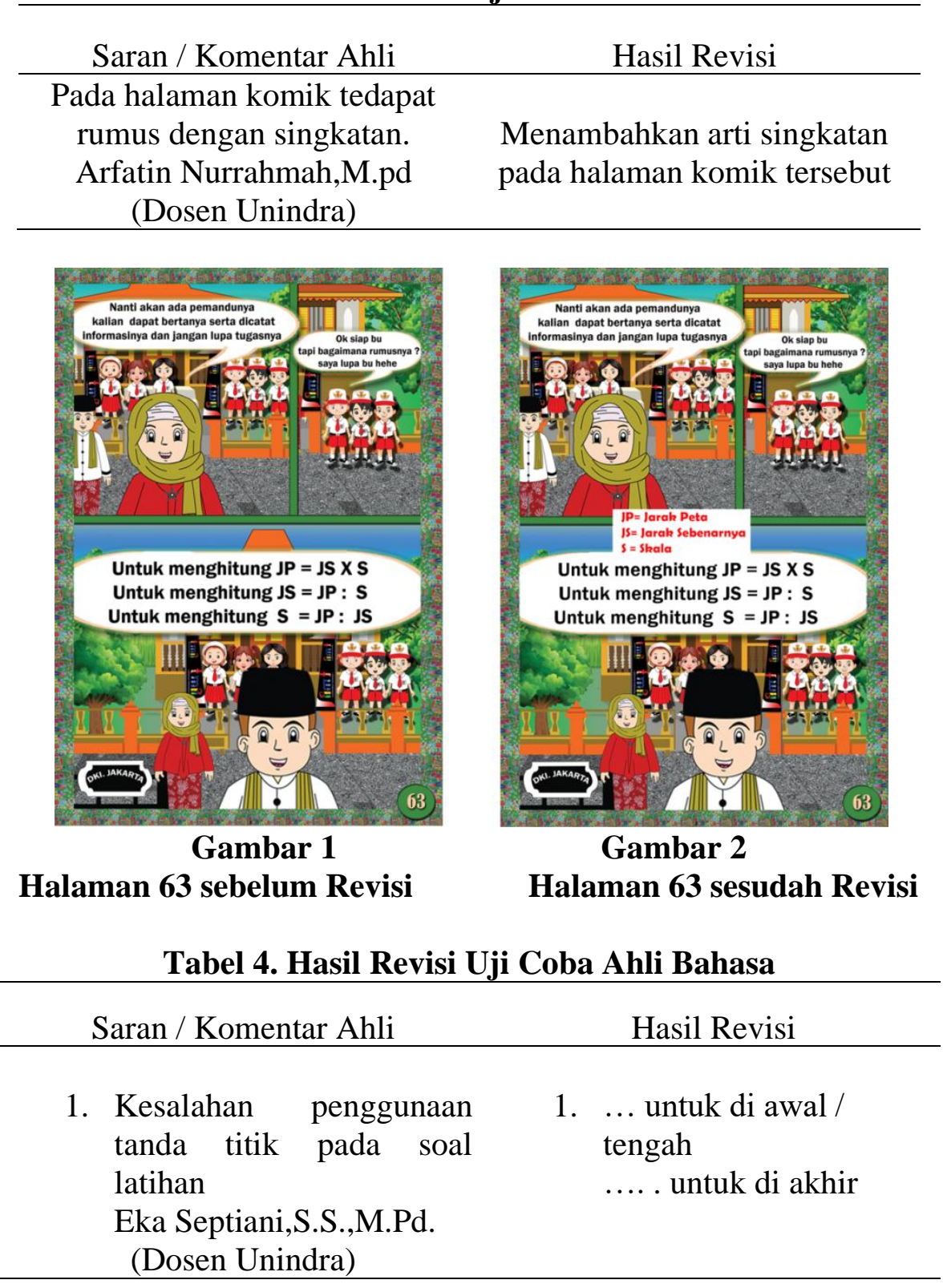




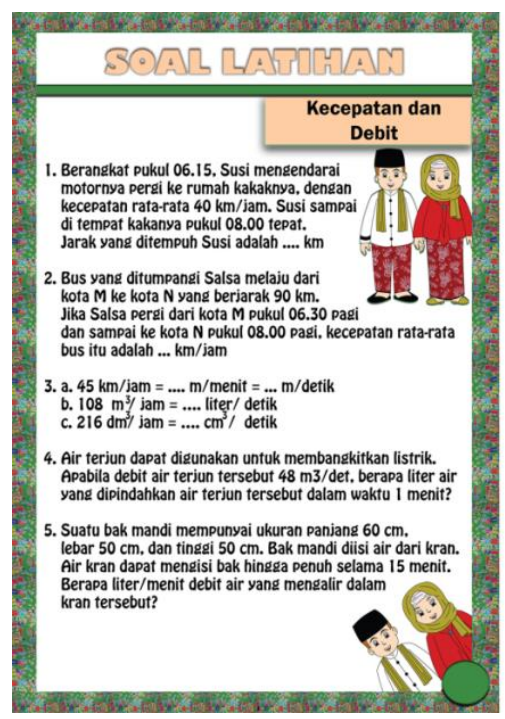

Gambar 3

Soal Latihan sebelum Revisi

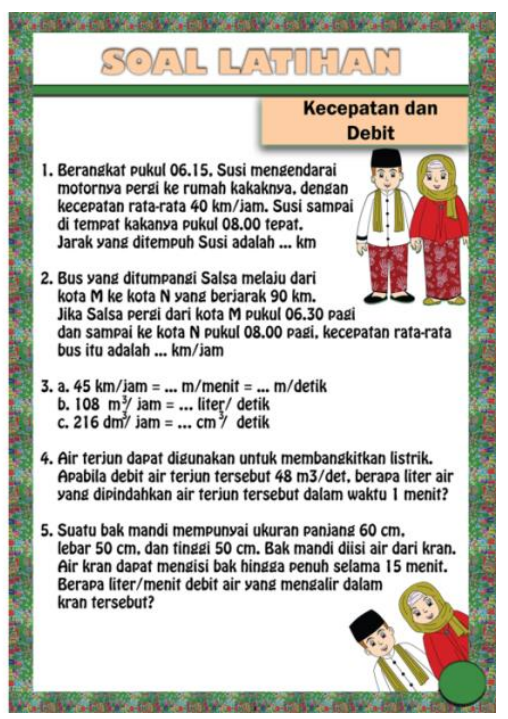

Gambar 4

Soal Latihan sedudah Revisi

Tabel 5. Hasil Revisi Uji Coba Ahli Media

Saran / Komentar Ahli

Hasil Revisi

Pada cover belakang pemilihan warna teks dan background kurang kontras (putih \& kontras),

Yogi Wiratomo, M.Pd.

(Dosen Unindra)

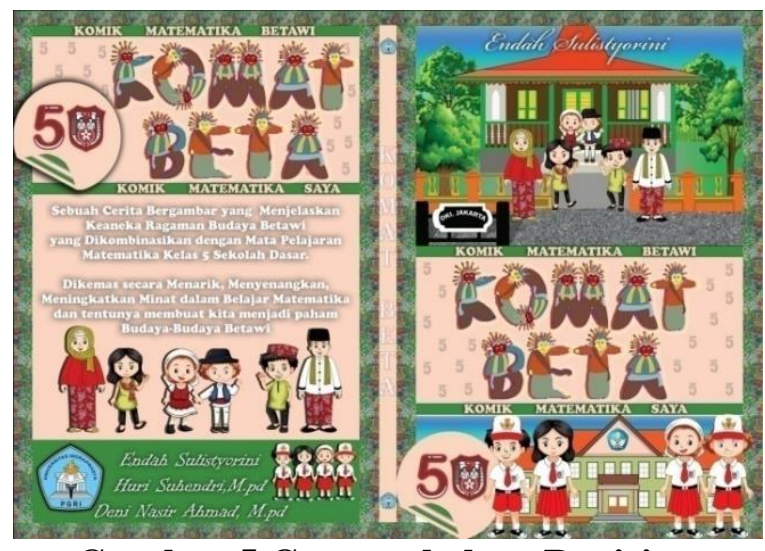

Gambar 5 Cover sebelum Revisi

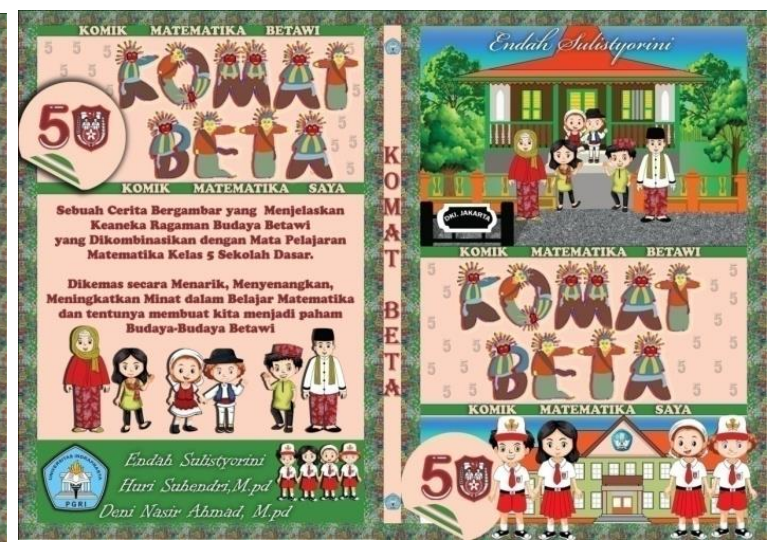

Gambar 6 Cover sesudah Revisi

Tabel 6. Hasil Revisi Uji Coba Ahli Pengembangan

Saran / Komentar Ahli

Hasil Revisi

Background warna pada bab 3

Hasbullah

Sesuaikan warna dengan kontekstual

(Dosen Unindra) 


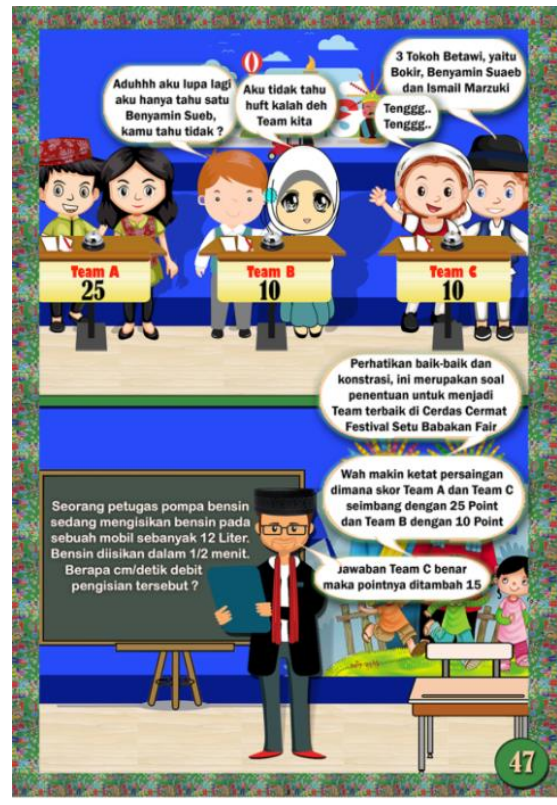

Gambar 7 Background bab 3 sebelum Revisi

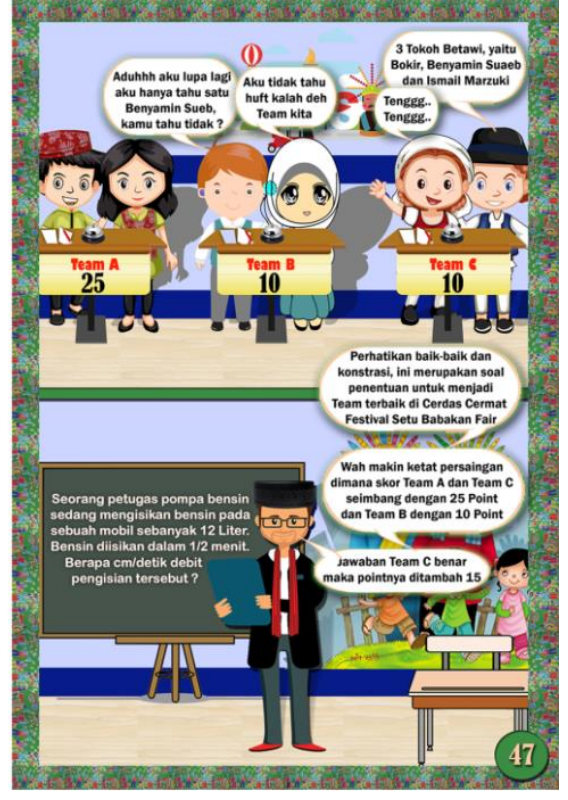

\section{Gambar 8 Background bab 3} sesudah Revisi

\section{Pembahasan Penelitian}

Hasil penelitian ini pengembangan ini adalah tersusunnya media pembelajaran bernuansa komik untuk memfasilitasi peserta didik dalam pencapaian tujuan pembelajaran dan dapat meningkatkan minat belajar matematika peserta didik. Suparman (2012:118) menyatakan kebutuhan merupakan suatu kesenjangan yang terjadi saat ini dibandingkan dengan keadaan yang diinginkan. Sekolah dasar kelas V merupakan peserta didik yang sudah dituntut untuk memahami serta menguasai kompetensi-kompetensi dasar matematika untuk bakal mereka dijenjang pendidikan selanjutnya yang lebih sulit.

Peneliti melakukan studi pendahuluan kepada tiga sekolah dalam satu kecamatan yaitu SDN 02, 03, dan 016 Pondok Labu, Jakarta Selatan. Disimpulkan bahwa kurikulum yang digunakan adalah kurikulum 2013 sehingga peserta didik dituntut untuk lebih kreatif dan inovatif dalam pembelajaran sehingga guru harus menjadi inspirator dan fasilitator karena peserta didik harus memiliki kompetensi kemampuan menganalisa. Guru harus mencari solusi untuk peserta didik karena banyak ditemukan kasus peserta didik sulit untuk memahami soal matematika berbentuk soal cerita. Setelah melakukan pengamatan peserta didik kelas V SD lebih antusias jika belajar menggunakan media pembelajaran dibandingkan hanya dengan metode konvensional.

Dalam sebuah produk sudah pasti memiliki kelebihan dan kekurangan, termasuk media pembelajaran yang penulis kembangkan. Kelebihan media komik yang penulis kembangkan memiliki ciri khas yaitu kearifan lokal yaitu Budaya Betawi, diantaranya menggunakan karakter yang berciri khusus adat betawi, selain itu menggunakan alur cerita dan gaya bahasa Budaya Betawi. Pendesain mengangkat tema kearifan Budaya Betawi karena suku betawi sebagai penduduk asli DKI Jakarta yang merupakan Ibu Kota Negara Indonesia, sehingga peserta didik minimal harus mengetahui sebagian budaya-budaya yang harus dilestarikan. Kearifan Budaya Betawi tersebut dikombinasikan dengan kisah pesahabatan yang terjalin seperti halnya dalam kehidupan nyata, sehingga mempermudah pemahaman peserta didik. Selain itu, Media Pembelajaran komik matematika ini terdiri dari 2 (dua) semester yaitu dengan materi semester 1 (satu) yaitu penjumlahan dan pengurangan pecahan, perkalian dan pembagian pecahan, kecepatan dan debit, serta denah dan skala. Materi Semester 2 (dua) yaitu volume kubus dan balok, jaring- jaring bangun ruang, serta penyajian dan penafsiran data tunggal, sehingga mempermudah peserta didik mempelajari semua materi di kelas V SD. 
Nadiah dkk (2019:145) melakukan penelitian dengan tersedianya pembelajaran komik matematika tingkat Sekolah Dasar sudah tidak lagi monoton berupa ceramah atau komunikasi satu arah dari guru ke siswa. Komik matematika ini sebagai fasilitas bagi guru bahkan orang tua dari siswa untuk rangkaian kegiatan belajar, baik di sekolah maupun di rumah. Konseptual materi matematika tingkat sekolah dasar sudah ditampilkan dalam bentuk cerita dalam komik. Konseptual materi tingkat Sekolah Dasar sudahn ditampilkan dalam bentuk cerita dalam komik. Substansi kajian berupa konsep dan simbol dalam belajar matematika dapat disampaikan guru dan orangtua dengan komik matematika ini. Sejalan dengan Sundayana (2016:29) yang menyatakan bahwa, "dengan menggunakan media, konsep dan simbol matematika yang tadinya bersifat abstrak menjadi konkret". Dengan demikian, pengenalan konsep statistika yang umumnya hanya disampaikan melalui ceramah satu arah, dengan komik strip matematika ini sudah tidak lagi terjadi. Karena siswa sudah dapat informasi tambahan berupa interaksi dengan komik.

Namun komik yang peneliti kembangkan mempunyai kelemaham- kelemahan diantaranya biaya pembuatan komik cukup mahal, terbatasnya akses untuk melihat komik yang penulis kembangkan, peserta didik belum terbiasa menggunakan komik sebagai bahan media pembelajaran matematika sekolah sehingga perlu bimbingan. Namun diantaranya kelebihan dan kelemahan, produk yang peneliti kembangkan dapat digunakan melalui komik digital yang berbentuk Pdf, yang lebih mudah untuk dibaca oleh peserta didik serta dapat menghemat biaya dalam pencetakan komik. Media komik yang peneliti kembangkan masih harus diuji kelayakannya secara kontinu (terus menerus) karena uji yang dilakukan oleh penulis hanya uji terbatas, hanya melibatkan beberapa ahli bidang studi (praktisi), ahli bahasa, ahli materi, ahli media dan ahli pengembangan. Produk yang peneliti kembangkan masih sangat jarang ditermukan dalam proses pembelajaran matematika di sekolah karena pada unumnya sekolah menggunakan metode konvensional, oleh karena itu peneliti mengembangkan media komik matematika sebagai pendamping buku reverensi belajar selain buku pelajaran dari sekolah untuk peserta didik kelas V Sekolah Dasar.

\section{KESIMPULAN}

Berdasarkan hasil dan pembahasan, dapat disimpulkan bahwa pengembangan media pembelajaran berbentuk komik di SD bertujuan untuk memberikan gambaran secara menyeluruh proses mengembangkan media pembelajaran matematika. Pengembangan media ini pada akhirnya menghasilkan media komik matematika untuk SD kelas V yang terdiri dari 2 semester, dengan semester pertama terdiri dari penjumlahan dan pengurangan pecahan; perkalian dan pembagian pecahan; kecapatan dan debit; serta denah dan skala. Semester dua terdiri dari volume kubus dan balok; jaring-jaring bangun ruang; serta penyajian dan penafsiran data tunggal. Media ini dapat membantu para guru dalam menjelaskan materi di kelas sebagai pendamping media yang sudah ada sebelumnya. Selain itu, media ini dapat digunakan peserta untuk lebih antusias dan tidak memberikan rasa bosan.

Adapun saran pemanfaatan dan pengembangan produk lebih lanjut adalah sebagai Media pembelajaran komik matematika Sekolah Dasar kelas V dalam desain media pembelajaran hasil penelitian ini sangat memuaskan dan baik digunakan sebagai bahan tambahan sumber belajar dalam pembelajaran matematika berdasarkan pemahaman materi. Dalam menghemat biaya penggandaan untuk memperbanyak media pembelajaran komik matematika Sekolah Dasar kelas V ini maka pendidik dan peserta didik dapat memanfaatkannya dalam bentuk soft copy dan dapat digunakan dalam bentuk komik digital.

\section{DAFTAR PUSTAKA}

Fauziah,A. dan Asih Rosnaningsih. (2017). Hubungan antara Motivasi Belajar dengan Minat Belajar Siswa kelas IV SDN Poris Gaga 05 Kota Tanggerang Jurnal JPSD 4(1) http://dx.doi.org/10.12928/jpsd.v4i2.9594 
Ma'mur,Jamal. (2012). Pendidikan berbasis keunggulan lokal. Yogyakarta: Diva Press

Maunah, Binti. (2016). Sosiologi Pendidikan. Yogyakarta: Kalimedia.

Nadiah,S. dkk. (2019). Desain Komik Strip Matematika pada Materi Statistika untuk Kelas VI Tingkat Sekolah Dasar. JKPM (Jurnal Kajian Pendidikan Matematika) 4(2):135-145. https://journal.lppmunindra.ac.id/index.php/jkpm/article/view/3870

Nasution, Toni. (2018). Membangun Kemandirian Siswa Melalui Pendidikan Karakter. Ijtimaiyah Jurnal Pendidikan Dan Ilmu Sosial 2(1): 1-18 http://jurnal.uinsu.ac.id/index.php/ijtimaiyah/article/download/2925/1731

Nugroho,S. dan Ali Shodikin. (2018). Keefektifan Pembelajaran Student Teams Achievement Division (STAD) Berbantuan Komik pada Siswa SD. JMPM (Jurnal Matematika dan Pendidikan Matematika)"3(1)22-32.

http://journal.unipdu.ac.id:8080/index.php/jmpm/article/view/1067/0

Purwanto,N. (2012). Prinsip-prinsip dan teknik evaluasi pengajaran. Bandung: Rosda karya.

Siagian, Muhammad Daud. (2016). Kemampuan Koneksi Matematika dalam Pembelajaran Matematika. Journal of Mathematics Education and Science 2(1):58-67. https://jurnal.uisu.ac.id/index.php/mesuisu/article/view/117/94

Smaldino, Sharon E. (2011). Instructional Technology \& Media for Learning. In Jakarta: Kencana Predana Media. http://library.fip.uny.ac.id/opac/index.php?p=show_detail\&id=4830

Sundayana, R. (2016). Media dan Alat Peraga dalam Pembelajaran Matematika. Bandung: Alfabeta.

Suparman, Atwi. (2012). Desain Instruksional Modern, Panduan Para Pengajar dan Inovator Pendidikan. Jakarta: Erlangga.

Sutisna. (2010). Analisis Kesulitan Menyelesaikan Soal Cerita Matematika Pada Siswa Kelas IV MI Yapia Parung-Bogor. Artikel Ilmiah UIN Syarif Hidayatullah. 